\title{
Some notes on writing a commentary: Isaiah 1-12
}

A Groenewald

(University of Pretoria)

\section{ABSTRACT}

\section{Some notes on writing a commentary: Isaiah 1-12}

I was requested by the editors of the "Historical Commentary on the Old Testament" (HCOT) to contribute two volumes on Isaiah in this series. This present article, however, focuses only on volume I: Isaiah 1-12. The aim of this article can be summarised in six points. Some introductory remarks are made with regard to the genre of commentary writing. Secondly, the viewpoint of the HCOT series is outlined; in other words its methodological and epistemological viewpoint. Thirdly, recent developments in the study of the book of Isaiah are discussed. Fourthly, my own objectives and hypothesis with regard to this project are outlined. Fifthly, a short overview of Isaiah 1-12 on a synchronic level is given. Sixthly, my research methodology is defined as a "diachronically reflected synchronic" reading of the Isaianic text. In the last section some concluding remarks are made.

\section{INTRODUCTION}

I was requested by the editors of the Historical Commentary on the Old Testament (HCOT) to contribute two volumes in this series on the book of Isaiah, namely part I, volume I (chapters 1-12) and part I, volume II (chapters 13-27). The present article, however, only concerns part I, volume I: chapters 1-12 and will therefore only focus on the first main part in the book of Isaiah. This series is published by Peeters Publishers in Leuven (Belgium). HCOT is an international and ecumenical series of commentaries which devotes explicit attention to the history of interpretation of the biblical tradition in all its stages, both within as well as beyond the Hebrew canon (Beuken 2000:ix-x; Koole 1997:xi-xiii). The team of Old Testament scholars who committed themselves to contribute to this series consists of scholars from all over the world, from different churches and denominations. The commentary is intended not only for Old Testament (OT) scholars, but also for pastors, ministers of religion and other interested parties.

There was a time when commenting on a text amounted to little more than philological notes and philological assistance, for 
example, by inserting into the text a brief comment or by adding a marginal note explaining an unusual form. The kind of assistance such commentaries offered, was still fairly naïve, since it allowed readers to make up their own minds regarding the meaning of a text as a whole. Nowadays, however, commentaries are peri-literature (namely an own independent genre) discussing particular logical and other problems in literary texts. Commentators have thus become active agents in the creation of meaning and have started to direct readers in accepting particular interpretations of texts (Deist 1997:369).

It was inevitable that the broad gamut of exegetical methods which have emerged in the last decades would ultimately lead to an examination of the very occupation of explaining Biblical texts. Hermeneutics is now a recognised and necessary component of any exegetical endeavour (Beuken 2000:ix; Körtner 2006:75; Oeming 1998:1). Any commentary on a biblical book, therefore, is obliged to begin with a description and justification of its hermeneutical presuppositions if it wishes to avoid indoctrination. The problem is not the text, but those who interpret the text. Even when exegetes profess a high regard for religion and history, a love of literature and an acceptance of the Bible as the word of God, their beliefs and opinions continue to govern their explanation of the text and thus limit the Scriptures' almost limitless potential. Hermeneutics has demonstrated the significant and inevitable role interests and intertexts play in the process of interpretation. Hermeneutics has furthermore shown that interpretation constitutes a creative rather than a mere receptive activity.

According to Davies (1986:43) the production of a new commentary is prompted by new knowledge about the Biblical world, as well as changes in the scholarly world. The following can be added: although all commentators may recognise the Bible as a central document in various cultures and faith communities, there are various hermeneutical perspectives on the Bible (ranging from, for instance, conservative to liberal or revolutionary). Each perspective creates a subculture within the reading community. For its continued existence, it is of the utmost importance that members understand the Bible from a specific perspective.

Just as there are many reasons why people write Biblical commentaries, there are many reasons for an exegete to employ a 
particular method in his/her commentary (Deist 1997:375). The choice of an exegetical method is no arbitrary or innocent affair. It is determined by an exegete's social group, theological convictions, theory of meaning and the motivation for his/her writing a commentary. The choice of an exegetical method depends inter alia on a number of prior methodological and epistemological decisions. Whether or not exegetes are aware of the epistemological implications of the exegetical model they use, and whether or not they consciously reflect on these issues, the method they apply entails methodological and epistemological decisions that have major consequences for the theological and exegetical argument. The more exegetes reflect on what they are actually doing while interpreting texts, and the more they are prepared to reveal the constituent parts of the frames in which they place texts for the sake of interpretation, the more it becomes possible for different exegetes to speak about the same "phenomenon" and to debate the observations made (Deist 1997:381).

\section{VIEWPOINT: HISTORICAL COMMENTARY ON THE OLD TESTAMENT (HCOT)}

HCOT is a commentary series written by an international team of contributors. The operative word in the title is "historical", by which is meant to convey a specific perspective on the writings of the Old Testament (cf Koole 1997; Spronk 1997). As the term "Old Testament" indicates, the commentary stands in the Christian exegetical tradition. The contributors, representing a wide range of denominational affiliation, will treat the history of both Jewish and Christian interpretation with due respect, but are also free to take their own stance on controversial matters.

This commentary series seeks to be both up-to date with regard to contemporary scholarship and also be in touch with the centurieslong tradition of exegetical reflection on the OT. On the one hand, it is impossible nowadays to present a fully argued exegetical case without referring to the flood of new information which constantly becomes available in such disciplines as archaeology and philology (Koole 1997:xi). The wealth of information on any biblical text is so overwhelming that a good recent commentary will often need to be more extensive than its predecessors. On the other hand, theological exegesis cannot just dismiss previous scholarship in its field. There 
is a wealth of largely untapped exegetical wisdom that is available in the history of biblical interpretation.

In contrast to the a-historical approach of much of contemporary reader-oriented exegesis, in which it is mainly the interaction between the modern reader and the final text that matters, the textual analysis in this study is committed to an approach which takes seriously the historical embeddedness of the biblical text or the message of the book. The Old Testament is the product of a long and complex process of transmission, and as part of the sacred Scriptures which have been embraced by both Judaism and Christianity (the Hebrew Bible/Old Testament), it is rooted in the concreteness of human history, and cannot be properly understood apart from these historical roots (PBC 1993:41).

Since this commentary series is intended to serve not only the guild of Old Testament scholars, but also pastors and the educated laity, it is designed in such a format to serve a wide readership. The exegetical approach offered by the present commentary is governed by the project proposed for the series HCOT $^{1}$.

The book of Isaiah is like a mighty oratorio whereby Israel sings the story of its faith. Like any oratorio, this one includes interaction among many voices, some of which are in dissent. Like any oratorio, this work requires a rendering. The discussion of every pericope of the biblical text consists of a new translation of the pericope in question. The translation is a new rendering, based entirely on the Hebrew text (the Masoretic Text - BHS). The translation is followed by the heading "Essentials and Perspectives", under which the results of the exegesis is summarised in nontechnical language (Koole 1997:xii). In this section, knowledge of the biblical Hebrew is not assumed, and the exegetical exposition is based primarily on the final shape of the text. However, if various strata are discerned in the growth of the present text (redactional layers), it is appropriate to elucidate the meaning of every stratum in its own historical setting. Related passages elsewhere in the OT are also referred to in this section, especially those that can be regarded

1 In the "Editorial Preface (I)" of Isaiah Part 3, Volume 1 one can find the main contours of interpretation in so far as they direct the adopted methodology and are designed to serve the intended readership of scholars and educated theologians (Koole 1997:xi-xiii). 
as later applications or actualisations of the text in question. This is also the appropriate place for the treatment of significant exegetical insights in the history of Jewish and Christian interpretation beyond the OT itself - especially those found in the New Testament (NT). The emphasis here is thus primarily on the history of interpretation.

The section "Essentials and Perspectives" is followed by a longer, technical section "Scholarly Exposition", which contains the more detailed treatment of the exegetical issues (Koole 1997:xiixiii). In this section the full range of issues raised by modern critical scholarship is dealt with, namely questions regarding "Schriftgelehrte Prophetie" (scribal prophecy), authorship, dating, form criticism, tradition history, literary criticism, redaction criticism and composition criticism. Attention is thus paid to the meaning of every historical stage (redactional layers) which is discerned in the formation of the text, including its final canonical stage. In this stage the different layers are analysed whether they constitute independent layers, or rather layers classified as "Fortschreibung" ("a continued literary expansion of the text based upon the reinterpretation of its earlier material"). Tradition-historical and redaction-critical analyses should thus contribute to an inner-canonical history of textual interpretation.

\section{RECENT DEVELOPMENTS IN THE STUDY OF FIRST ISAIAH}

At the beginning of the $21^{\text {st }}$ century Isaianic studies are very different from what they were a few decades ago. What holds for all fields of study of the Hebrew Bible/Old Testament, holds no less for the interpretation of the book of Isaiah: in recent decades knowledge has increased exponentially and traditional hypotheses and methods have undergone such a process of refinement that they have practically disintegrated (Baker 1999:266; Becker 2004:31; Berges 1999:118-120; Berges 2000:168-171). The last decades of Isaianic studies have been characterised by a widespread questioning of "assured results" and a willingness to ask new questions and venture down new avenues. New insights question the old suppositions as well as the epistemologies underlying these suppositions. Current discussion of the book of Isaiah as a whole is rooted in earlier debate concerning the literary growth of the book and its major components. 
Recent research on the book of Isaiah is characterised by an increasing diversity in scholarly approach ${ }^{2}$. A matter of controversy is the so-called $8^{\text {th }}$-century core of the book, and the view of the historical prophet ${ }^{3}$. It is possible to single out two major changes in recent Isaianic studies. Firstly, the emphasis on Isaiah as a prophetic personality has changed into emphasis on the book of Isaiah $^{4}$. Secondly, as the focus of interpretation had shifted to the book as a whole, the strictly tripartite division of the book was challenged (De Jong 2007:5).

It is important to note the following general remarks with regard to the history of the exegesis of the book of Isaiah. Since Bernhard Duhm (1892:7-15) Isaianic scholarship has been dominated by the division of the book of Isaiah into three books,

2 Becker (2003:123) describes this situation as follows: "Die Jesajaforschung der Gegenwart ist gekennzeichnet durch eine große methodisch-hermeneutische Vielfalt, die unmittelbar Einfluss hat auf die erzielten Ergebnisse. Diese Lage ist angesichts des hochkomplexen Gegenstands kaum verwunderlich." For an overview of the history of research, compare Becker (1999:1-37, 117-152); Berges (1998:11-49); Hardmeier (1986:3-31); Höffken (2004); Seebaß (1995:315-318); Sweeney (1993:141162); Tate (1996:22-56).

3 According to Köckert (2003:112) "die Suche nach dem historischen Jesaja erweist sich als überaus schwierig”. Barthel (2003:125) infers as follows: "Wer sich in der aktuellen Situation der Prophetenforschung auf die Suche nach dem »historischen « Jesaja begibt, sieht sich mit einer Reihe schwerwiegender Probleme und Fragen konfrontiert". Cf. also Ackroyd (1978:16-48); Berges (2008:3) and Jeremias (1999:19-35).

4 According to Steck (1996:17) "[d]as ist jetzt die Lage: Vor dem Propheten steht das Buch. Wer zum Propheten will, ist zuerst an das Buch gewiesen. Gegenüber der lange alles dominierenden Rückfrage nach den prophetischen Person ist deshalb die klärende Nachfrage nach den prophetischen Büchern jetzt die vordringliche Aufgabe." Cf also Becker (2004:30-31): "Wenn man einen Trend in der Prophetenforschung der letzten Jahrzehnte - etwa seit den 70er Jahren des 20. Jahrhunderts - ausmachen wollte, so kann man von einer Wiederentdeckung des Prophetenbuches sprechen. Man hat gelernt, die Bücher der Propheten (wieder) als Bücher, als literarische Werke sui generis zu lesen und zu interpretieren, man hat Interesse daran gefunden, ihre Entstehung von deren Anfängen bis zur Endgestalt zu rekonstruieren und sie als Spiegel der Glaubensgeschichte Israels zu betrachten; und man hat dabei erfahren, dass die großen theologischen Gedanken nicht immer nur von den (vermeintlich) großen Propheten stammen müssen." 
namely Proto-Isaiah (1-39); Deutero-Isaiah (40-55) and Trito-Isaiah (56-66) (Beuken 2003:27; Höffken 2004:19). Duhm's paradigm holds that chapters 1-39 must be associated with the $8^{\text {th }}$-century prophet, Isaiah ben Amoz; chapters 40-55 are the work of an anonymous prophet of the Babylonian exile identified only as Deutero-Isaiah, and chapters 56-66 reflect the work of a post-exilic prophet identified as Trito-Isaiah. Traditionally the three books are thus ascribed to the following historical periods: Assyrian, Babylonian and Persian.

For most of the $20^{\text {th }}$ century, scholarly research was done as if these three parts comprised completely independent books. This approach resulted in exegetes, for the major part of the $20^{\text {th }}$ century, to approach First Isaiah in relative isolation from the rest of the book (Höffken 2004:27). The exegesis of First Isaiah was marked by relative consensus. The main exegetical task was seen as the identification and the description of the views and the preaching of the historical prophet, which even led scholars to make a distinction between "authentic" and "unauthentic" material within First Isaiah (Becker 1968:44-68) $)^{5}$. This approach, however, is quite atomistic: the core of First Isaiah was regarded as a collection of the $8^{\text {th }}$ century's prophetic texts to which divergent fragments were added in the exilic and post-exilic period. The prophet's life and ministry were important for exegesis and he was perceived as one of the great prophets, who lived and worked in $8^{\text {th }}$-century Judah and Jerusalem (ca 740-701 BCE) ${ }^{6}$. The text of First Isaiah was thus analysed and even reconstructed in conformity with the supposed spirit and teaching of the prophetic personality.

$5 \quad$ Cf also Becker (2004:41): "Eigentliches Ziel der Exegese ist nicht (mehr) die Herausarbeitung der ältesten Textbestände und die Freilegung des genuine prophetischen Gutes, sondern das Verständnis des gegebenen Buches in seinem geschichtlichen Gewordensein. Denn da das gegebene Buch eine literarisch wie theologisch außerordentlich komplexe Größe darstellt, die sich keineswegs von selbst versteht, ist man auf eine redaktionsgeschichtliche Analyse angewiesen."

6 According to Von Rad (1968:154) the preaching of Isaiah represents the theological high water mark of the whole Old Testament. No other prophet surpasses Isaiah in intellectual vigour or, more particularly, in the magnificent sweep of his ideas. Even the ideas which he took over from the tradition were mostly remodelled in the most daring way. 
Isaianic studies, like biblical studies, have undergone a paradigm shift in the past decades ${ }^{7}$. We have experienced a move from the "three-book interpretation" to a "one-book interpretation" once again (Berges 1998:12-15) ${ }^{8}$. More recent research on the literary character of the book of Isaiah has confirmed this new viewpoint. It should, however, be categorically stated that this latest move is to be differentiated from a fundamentalistic viewpoint, which still holds the following opinion that "the essential content of the book has come to us through one human author, Isaiah the son of Amoz" (Oswalt 1986:25).

In the latter part of the $20^{\text {th }}$ century the focus on redaction criticism caused increasing attention to the literary afterlife of the prophetic texts (Berges 2006:190-197; 2008:3-4). Scholarly focus moved away from the historic prophetic personality of Isaiah to the book of Isaiah as a literary product (Sweeney 1993:141; 2005:1). In his commentary on First Isaiah, Wildberger (1965-1982) focused mainly on Isaiah as the prophet-theologian, and his commentary can thus be regarded as the culmination of the earlier approach. The focus away from the $8^{\text {th }}$-century prophet to the history of the development of the book of Isaiah was first introduced by Otto Kaiser in his revised edition of his commentary on Isaiah 1-12 (Kaiser 1981).

The new insight that grew among scholars was that the different parts of the book of Isaiah were more intertwined than a strict division of the book in three parts would allow the exegete to recognise (Berges 1998:12-15, 41-49; Becker 2004:40) ${ }^{9}$. The

7 In this regard Becker (2004:31) infers as follows: "Es ist modisch geworden, jede Trendwende mit dem Begriff Paradigmenwechsel zu belegen; hier hat er indes seine Berechtigung."

8 The remark thus made by Rendtorff in 1984 (:295) that the question about the composition of the book of Isaiah in the form in which we now have it, is not one of the generally recognised subjects of Old Testament Studies, does not hold true anymore. The focus and face of Isaianic Studies have changed radically since 1984 .

9 Joachim Becker (1968:33) had already commented in 1968 as follows in this regard: "Das Buch spricht also zum Leser, nicht unmittelbar der Prophet. Das Buch spricht aber als Einheit; bei der Lektüre der ersten Kapitel mu $\beta$ man die letzten schon vor Augen haben." Cf also Berges (2008:3): “Zumindest für das Jesajabuch gilt: Es ist zu disparat, um als einheitlich, und zu einheitlich, um als völlig disparat gelten zu können. Auf diachroner und damit produktions- 
exegetical emphasis turned to the book of Isaiah as a whole, and the issue of the compositional, redactional and theological unity of the book became the main focus of Isaianic research (Becker 1999:3-4; Steck 1996:12) ${ }^{10}$.

These developments had a major impact on the study of First Isaiah, as well as for the first main section Isaiah 1-12. It is an accepted fact that this part of the book does not only contain early material, but also material from later or even from the latest redactional stages that the book underwent. As a result of this development scholars have shifted their interest away from reconstructing the events and historical personages mentioned in the biblical tradition and have argued that the image of the prophet which emerges from the book is first and foremost a literary character (Becker 2004:31). Scholars have become increasingly aware of the gap between the book and the historical prophet - even emphasising the impossibility of bridging this gap.

In Isaianic research the focus is now however on identifying the literary work and theological perspectives of the anonymous tradents and redactors who shaped this tradition ${ }^{11}$. Although historical reconstruction continues to play an important role in critical research, scholars increasingly pay more attention to the literary character and setting of the texts, including their structure and thematic development, their redactional information and intent, and their social and institutional matrices.

hermeneutischer Ebene kann es nur darum gehen, das gewachsene Zeichenund Bedeutungsgeflecht an seinen Nahtstellen behutsam zu öffnen, ohne diesem Gewalt anzutun und es zu zerstören."

10 Berges (2006:190) formulates this conviction as follows: "Daher lautet das aktuelle Motto der Prophetenforschung: vor dem Wort steht das Buch!"

11 According to Berges (2006:190) "es zeigt sich zusehends, dass das Zustandekommen dieser literarischen Kathedralen nicht ohne die Mitwirkung von Schüler- und Tradentenkreisen möglich gewesen ist. Dabei handelt es sich nicht um bloße Sammler oder gar einfallslose Nachahmer, sondern um geschulte Literaten, die Altes und Neues auf kreative Weise verbanden und die Kompositionen für ihre jeweilige Zeit fortschrieben". 


\section{OBJECTIVE AND HYPOTHESIS OF THIS PROJECT/ COMMENTARY}

The objective of this project is governed by the aims and goals as outlined by the editors of the series HCOT (Beuken 2000:ix-xii; Koole 1997:xi-xiii). In this commentary the relationship between the genesis of the text of Isaiah 1-12 and its final form is examined, between the centuries-old history of exegesis of these texts and their contemporary expressions. Explicit attention is devoted to the history of the interpretation of the book of Isaiah and specifically chapters 1-12 - as can be discerned within the Hebrew canon itself and as it has continued subsequent to the closing of the Old Testament canon. In this commentary attention is given to contemporary scholarship, as well as the centuries-long tradition of exegetical reflection on Isaiah 1-12. Theological exegesis cannot write off previous scholarship in its field.

This commentary's research question is thus of a twofold nature: firstly of a literary nature; and secondly of a historical nature. This research question has led to the formulation of the following hypothesis: the text of Isaiah 1-12 is the product of a multi-stage redactional-compositional process. A thorough text-immanent (intratextual) analysis, combined with an inter-textual and extra-textual analysis, indicates a developmental history of the text of Isaiah 1-12 in different layers. In spite of the fact that chapters 1-12 of the book of Isaiah are presented as a single block of literature occurring at the beginning of the book of Isaiah, a detailed analysis of its content demonstrates that it is a composite work written over the course of some centuries (Becker 2004:34). The many interrelationships between the various parts of the book of Isaiah indicate successive rereadings of the Isaianic tradition in the light of later historical circumstances.

Whereas the earlier exegesis of First Isaiah mostly concentrated on the identification of the "authentic" Isaianic material, implying that the so-called "unauthentic" texts were theologically less significant, the rise of redaction criticism stimulated the appreciation of texts reflecting later developments in the development of the book (Berges 2008:4). It has become a generally accepted viewpoint that priority should be given to the text, namely to the book of Isaiah in its final form. However, the study of the text includes the historical questions of how the text has 
come into being, namely the question concerning the development of the tradition in the book. Scholars have thus rightly argued that the point of exegetical departure must be what we have, the text of Isaiah, and not any preconception about the historical prophet and his preaching (Berges 1998:47). However, exploration of the origins and the earliest development in the Isaianic tradition must and should remain part of the exegetical agenda.

With regard to the historical explanation of the text, the analysis proposes a hypothesis on the genesis of chapters 1-12 of the book of Isaiah (Beuken 2000:x). This may include the possibility of distinguishing oracles of Isaiah ben Amoz himself, or reports concerning the prophet stemming from his immediate environment, from new applications thereof provided by the course of transmission. This includes the endeavour to discern the motivations behind the actualising tradition of Israel's prophecies and their redaction $^{12}$. This analysis strives to determine whether a particular revision dates from before, during or after the exile, given the fact that the fall of Jerusalem constituted such a profound demarcation between the theological parameters of these periods. Following the recent shift of perspectives regarding the book as a whole, the first part of the book of Isaiah can no longer be regarded as consisting of an $8^{\text {th }}$-century "Proto-Isaiah" plus a series of extras. Instead, the book of Isaiah is regarded as a literary product of a much later period (De Jong 2007:39). Throughout the book of Isaiah we find evidence of redactional attempts to establish literary structures within the book as a whole, implying that passages within First Isaiah - thus also Isaiah 1-12 - may belong to the latest redactions. The Isaianic tradition thus underwent a complex development in the course of centuries $^{13}$. Not only was new material added at various stages, but

12 In this regard Steck (1996:v) infers as follows: "Prophetenbücher gehen zwar unter einem Prophetennamen, allem Anschein nach sind sie aber nicht einfach von ihrem Propheten geschaffen, sondern über viel längere Zeit erst zu ihrem vorliegenden Umfang gelangt. Nicht der literarische Wurf eines Autors, sondern gewachsene Traditionswerke werden hier angetroffen."

13 In this regard Becker (2004:41-42) infers as follows: "Sie [redaktionsgeschichtliche Analyse] lehrt, das kanonische Jes-Buch als das Endprodukt einer sich über mehrere Jahrhunderte erstreckenden Lese- und Auslegungsbemühung $\mathrm{zu}$ verstehen, die gerade an der Aktualität des Gotteswort für die jeweilige Gegenwart festhält und es deshalb je neu interpretiert, es 'fortschreibt'. Insofern schließen sich - um zwei Schlagworte 
existing material was reworked and reinterpreted. First Isaiah is therefore not an anthology of pre-exilic material only supplemented and augmented by later elaborations, but actually forms part of an extensively edited literary compilation from post-exilic times that contains material from several ages. There was thus an ongoing tradition, which through a series of formative stages, resulted in the book of Isaiah ${ }^{14}$.

It seems that the earliest stratum of the book of Isaiah originates from the second half of the $8^{\text {th }}$ century, in which the main issue at stake in Judah was the question of whether or not to resist Assyrian imperialism (De Jong 2007:43). This stratum reflects the political controversy of the late $8^{\text {th }}$ century. It is considered justifiable to accept the existence of an Assyrian or Josianic redaction $\left(7^{\text {th }}\right.$ century $\left.\mathrm{BCE}\right)$, in line with the majority of contemporary commentators (Beuken 2000:x; De Jong 2007:40; Sweeney 1996:57-59). It is assumed that this redaction provided an older collection of the oracles of Isaiah with a new edition in the light of the national and religious revival which characterised the reign of king Josiah (640-609 BCE), during which the power of Assyria had begun to wane. It was this same tendency which transformed the withdrawal of Sennacherib's army in $701 \mathrm{BCE}$ into a paradigmatic narrative concerning Zion's inviolability under YHWH's protection (Beuken 2003:35). While He had used Assyria as an instrument of punishment and purification for Israel, He had never intended to abandon Israel as his dwelling place or to undo his promise to the house of David (Beuken 2000:x-xi).

More major redactional revisions can also be distinguished. The late $6^{\text {th }}$-century edition of the book of Isaiah appears to have been composed in conjunction with the building of the second Temple in Jerusalem. The rebuilding of the temple in Jerusalem and the role that Israel would assume in relation to the nations thereby

der neueren Forschung aufzugreifen - ein synchroner und ein diachroner Zugang zu den Prophetenbüchern nicht aus."

14 Cf Beuken (2003:10): "Wenn man in groben Zügen von einer vorexilischen, exilischen und nach-exilischen Redaktion der jesajanischen Orakel ausgehen darf, dann bedeutet das zugleich, dass man sich in Israel, von Anbeginn der prophetischen Überlieferung und über den Bruch des Exils hinweg, für diesen Prozess des kreativen Umgangs mit der Tradition legitimiert wusste." 
becomes the basis for the message of Isaiah in the $6^{\text {th }}$-century edition of the book (Sweeney 1996:56).

The final form of the book Isaiah was produced in relation to the reforms of Ezra and Nehemiah, and was concluded in the late $5^{\text {th }}$ learly $4^{\text {th }}$ century $\mathrm{BCE}^{15}$.

It is clear from the final canonical text of Isaiah 1-12 that the struggle to come to terms with the traumatic experience of the Assyrian threat in the $7^{\text {th }}$ century, the destruction of Jerusalem and the Babylonian exile in the $6^{\text {th }}$ century played an important role in this text. Judah's identity, as well the issue of re-defining identity in a totally new political dispensation, is all pervasive in these Isaianic texts ${ }^{16}$. A concern for judgement of both Israel and Assyria is combined with salvation and promise for Jerusalem, the redactors thus relating the message of the $8^{\text {th }}$-century prophet Isaiah ben Amoz to the situation of post-exilic Judah, which had already suffered the judgement and now anticipates the restoration. Far from being abandoned, the Isaianic tradition was thoroughly reworked in order to put it in line with a new view of Israel's past and to use the authority of the figure of Isaiah as a spokesperson of this new view.

The aim of the analysis in this commentary is to open a window on this text: from the significance of the book for the second Temple Judean community, living in the aftermath of the exile - to whom the final redaction was addressed - until and including the significance of the oracles for the prophet's audience on the eve of national calamity and ruin. It seems that the transmission and redaction have assumed a degree of continuity between the original audience and later readers (Beuken 2000:xii). Such continuity is not unusual at all with regard to both religious and secular texts which have enjoyed a degree of ongoing validity from their origin and conception.

15 Some scholars, however, regard the final date of revision to be the second century BCE (eg Kaiser 1983:1).

16 In this regard Beuken (2003:27) infers as follows: "Das prophetische Erbe Jesajas sollte das Volk Juda und später die Gemeinde des Zweiten Tempels darin unterstützen, die eigenen Identität zu begreifen, zu bewahren und zu entwickeln. Dies war auch notwendig, denn die damalige Welt sah eine Großmacht nach der anderen kommen und gehen ... Bei solch stürmischen Entwicklungen der Weltgeschichte liefen kleinere Völker Gefahr, ihre ethnischen und religiösen Eigenheiten zu verlieren." 


\section{ISAIAH 1-12: ZION AND JERUSALEM BETWEEN DESIRE AND REALITY ${ }^{17}$}

The initial collection of oracles in chapters 1-12 is certainly one of the most complex and controversial portions of the book of Isaiah. The book of Isaiah is a good example of the necessity to conduct a diachronic and a synchronic reading of texts ${ }^{18}$. The conventional division of the book, beginning with chapters 1-12, is a useful, though inadequate, starting point to account for the successive redactions that the book underwent in the course of its long history (Berges 2006:192; Blenkinsopp 2000:171). These redactions, their interconnectedness and continuities all belong to both the history of the book, as well as its total meaning. They are theologically and historically significant and therefore cannot be neglected in favour of the surface structure of the book's final form (Berges 2008:4).

There seems to be general agreement that chapter 1 constitutes some kind of introduction, although the scope covered by the superscription remains in dispute. Again, a wide scholarly consensus recognises a closure in chapter 12 , which is sharply distinguished from the succeeding oracles (Beuken 2003:30; Childs 2001:9) ${ }^{19}$. Isaiah 1-12 thus comprises a distinct section which begins with a superscription, attributing the book to the prophet Isaiah, and is concluded with a psalm that implies his name (12:1-6) and that invokes the "Holy One of Israel"; a title which recurs at regular intervals throughout these twelve chapters and which recalls the prophet's vision at their central point (6:3). Although this section gives the impression that it was planned as a distinct unit, it also connects thematically and linguistically with other parts of the

17 This discussion is a preliminary overview. The aim of this article does not allow for an elaborate discussion of either the content or all technical matters and complexities related to these twelve chapters.

18 Cf Childs (2001:4): "I remain critical of those interpreters who attempt to force exegesis into narrowly defined structuralist categories, or who restrict its only legitimate role to synchronic analysis. The relation of the synchronic and diachronic dimensions is an extremely subtle one in the Bible and both aspects must be retained."

19 Beuken (2003:32) confirms as follows: "Durch eine eingreifende literarische Bearbeitung wurde die Immanuelschrift $\mathrm{zu}$ einem selbstständigen Opus ausgebaut." 
book $^{20}$. As a result the poems, discourses and narratives in chapters 1-12 achieve a unity by coalescing into an overview of the triumph and eventual collapse of the Assyrian power (cf 10:1-34; 11:12-16) a theme which dominates the entire first section of the book (Isaiah $1-39)$.

Chapters 6-8 are the narrative nucleus of chapters 1-12. Very early in the critical study of these chapters an important hypothesis was developed under the rubric of Isaiah's memoir (Denkschrift). Accordingly, it was argued that the earliest core of the book was to be found in these chapters, which basically derived from the prophet's own historical experience (Childs 2001:9). More recently, this hypothesis has come under increasing attack and the issues call for closer examination ${ }^{21}$.

Isaiah 6-8 - the account in the first and third person of Isaiah's encounter with Ahaz during the time of Tiglath-pileser III around 734 BCE - was composed as a mirror image of the prophet's relations with Hezekiah at the time of Sennacherib, three decades later (Isaiah 36-37). With regard to these chapters (the Isaiah memoir or Denkschrift) it is important to distinguish between, on the one hand, early prophetic material, and on the other hand, reflective redactional material (De Jong 2007:24). Isaiah 6-8 seems to be a literary composition in which earlier prophetic words are incorporated and the intent of the literary composition differs from the earlier prophetic words. Chapters 6-8 in their basic literary version represent textual layers in which the earlier Isaianic tradition is extensively reworked and a new view of Isaiah's prophetic ministry is presented (Beuken 2003:30-31). These literary layers represent a thorough reworking of the Isaianic tradition in the light

20 With regard to these connections, Beuken (2003:36) infers as follows: "Was Kap. 1-12 betrifft, so geht besonders die »erste Ouvertüre« (1,2-2,5), stärker als »die zweite Ouvertüre« $(2,6-4,6)$, auf eine Bearbeitung zurück, die den Beginn des Jesajabuchs auf sein Ende in Kap. 65-66 abstimmt."

21 De Jong (2007:17-24) gives an overview of the development as well as decline of this hypothesis. In this regard he remarks as follows: "Once it is realised that Isa 6-8 is not a literary unit aus einem $G u \beta$ but a redactional composition, the authorship of Isaiah needs to be reconsidered. The Isaianic provenance of the hardening order (6:9-10) and the principle of the condition of faith (7:9b) are to be considered too. The Denkschrift-hypothesis can no longer function as a pillar of the exegesis of First Isaiah" (2007:19). 
of the events of the early $6^{\text {th }}$ century. The disastrous events of this century - the fall of Jerusalem, the collapse of the state, the end of the dynasty and the Babylonian exile - led to a profound reconsideration of the past (Beuken 2003:35).

Moral causality, according to which the vicissitudes of the people of Judah vis-à-vis successive imperial powers are explained with references to internal societal attitudes and behaviour, anchors these first twelve chapters of the book of Isaiah in the first wave of prophetic protest in the $8^{\text {th }}$ century BCE; thus the many similarities to the book of Amos which will also be discussed in this commentary.

The critique of imperialism does not only relate to the Assyrian empire, but is also applied with equal force to the Babylonian empire, who filled the vacuum created by the collapse of Assyria and which brought the Kingdom of Judah to a fall (Blenkinsopp 2000:172). It is therefore not surprising that at several points in Isaiah 1-12 we find allusions to the destruction of Judah and Jerusalem in the campaign of 589-586 BCE by the Babylonians. Chapters 1-12 are immediately followed by the first of many antiBabylonian poems and sayings in the book.

The persistent focus on the future which we encounter in chapters 1-12 did not end after the disaster of 587/6 BCE. Predictions of judgement, however, do not only implicate judgement, but also a positive outcome for Judah and Jerusalem $(1: 27-31 ; 2: 2-5$; $4: 2-4 ; 10: 20-23 ; 11: 10-16)$. It is thus easy to grasp why concern with the destiny of Judah and Jerusalem, which is firmly embedded in the Isaianic tradition, would reflect in the last section of the book (Isaiah 56-66), when the Jerusalemite temple was the focus and centre of the religious, political and social life of the Judean province under Persian rule.

The internal composition of Isaiah 1-12 confirms the point of repetitive structures. The first and foremost indication is the repetition of the superscription in 2:1. This duplication confirms the impression that Isaiah 1 is seen as the introductory chapter, which recapitulates themes occurring throughout the book. The present form of the chapter in the context of the book as a whole, dates to the latter part of the $5^{\text {th }}$ century and serves as the prologue to the book of Isaiah (cf Sweeney 1988:96, 123). Other indications of structure and order in this first section may be noted. For example, 
the vineyard song (5:1-7), which is reinterpreted later in the book (27:2-5), serves as a transition to the narrative core of Isaiah 1-12, dealing with Syrian-Samarian attack on Judah (Berges 1998:50ff). On one level of organisation the narrative core is put between the death of Uzziah, king of Judah (6:1), and that of his successor, Ahaz (14:28).

The narrative core of Isaiah 1-12 can be summarised as follows. Isaiah attempts to persuade Ahaz that he should not fear the Syrian-Samarian alliance and to dissuade him from taking illadvised countermeasures. These attempts all fail and Isaiah subsequently withdraws from involvement in public affairs chapters 7-8 with considerable editorial elaboration (Blenkinsopp 2000:173). The commissioning of his task (6:1-13) occurs in the first person, the body of the narrative in the third person $(7: 1-17)$ and the last part (8:1-18) again in the first person. The Isaianic core narrative (the Isaiah memoir/Denkschrift), with its many editorial elaborations is not a transcript of eyewitnesses, but rather a literary construct.

The core narrative is surrounded by sections of poems describing Assyrian military intervention in response to Ahaz's plea and the punishment of the aggressors going beyond their commission (5:26-30; 10:5-34 with redactional layers). While this poetic material is relevant to the situation during the reign of Ahaz, the possibility cannot be excluded that it was expanded at the time of Sennacherib's campaign in Judah three decades later. Also straddling the core narrative is a poem on the divine anger $(5: 25 ; 9: 7-20)$. Its location suggests that it serves to comment on the spiritual ignorance which manifested itself in the failed mission of 734 BCE. These sayings, different in length, direct specific indictments against the political, religious and intellectual leadership. The two poems describing the ideal Davidic dynasty $(9: 1-6 ; 11: 1-9)$ precede the announcements of Ahaz's death (14:28), and therefore express the hope of a better future by birth rather than by Hezekiah's accession.

These are the principal components of this section, but the numerous redactional expansions and adjustments (which will be pointed out in the commentary) testify to the text's relevance during later times: from the critical times of Hezekiah and Josiah, Judah under Babylonian rule, the establishment of a new commonwealth under Persian rule, and its further vicissitudes after the conquests of Alexander. 


\section{RESEARCH METHODOLOGY: DIACHRONICALLY REFLECTED SYNCHRONY}

This new paradigm shift in Isaianic studies ${ }^{22}$ manifests in several ways, the most important of which is the attention paid to the book as a coherent whole. As a result, one notices an increasing interest in Isaianic exegesis from the point of both redaction criticism as well as composition criticism (Berges 1998:11; Schmid 2007:308-310). When specific elements in a text are perceived as additions, the emphasis in exegesis is, at present, more on a possible "reconstruction" of the theological agenda of these stages of growth together with the "potential" group/groups responsible for these stages of growth. The focus is therefore placed more on identifying the literary work and theological perspectives of the anonymous tradents and redactors who shaped that tradition. Redaction history examines the text's growth from the first written edition through all the stages of development, compilation and editorial commentary, to its final form (Le Roux 1993:53). This comprises an explanation of the fusion of transmissions or traditions, the many additions and their influence on the text's final shape. In short, redaction history endeavours to organise and explain in terms of history. The importance of redaction history for the exegesis of the Old Testament is obvious. Firstly, a theological framework of the final redactor is provided. At a specific point in time the final editor shaped the final text and conferred a "final" meaning to it. Secondly, this meaning can be explained in terms of theological views of an earlier stage of development ${ }^{23}$.

Redaction criticism is thus a major step in biblical exegesis as the final redactors played a decisive role in shaping the final form of a biblical book - thereby determining its present literary structure

22 Cf no 3 - recent developments.

23 In this regard Deist (1994:288) postulates as follows: "Histories het hier ' $\mathrm{n}$ ideologie-kritiese bodem. Die teks (met sy boodskap word beskou as ' $\mathrm{n}$ produk van sosiale en ander omstandighede. Die historiese analise van die teks (gepaard met ander historiese inligting oor die tyd) moet derhalwe die ideologiese tendense uit die tekste rekonstrueer. Vir dié doel het die historiesekritiese eksegetiese metode homself aangebied, terwyl ' $n$ spesifieke geskiedteoretiese raamwerk die resultate van dié teksanalises in ' $\mathrm{n}$ samelewingskonteks plaas." Cf also O H Steck's (1995:79-98) discussion of the "redaction historical approach" in his book on Old Testament exegesis. 
(Sweeney 1993:147). Consequently, the overall structure, the genre, setting and intention of the book in its final form must be studied in order to identify the perspectives and the literary character of the final redaction. This synthetic step provides the basis for analytical work designed to identify earlier textual stages and thereby to determine the hermeneutical perspectives and influences of the text's redactors in shaping the final form of the text.

The redaction-critical endeavour is combined with a canonical reading of the text: that is the question regarding the significance of the position of the individual text for the interpretation of specifically this text. Some recent studies have begun to note ways in which the form of the book of Isaiah suggests the presence of editorial processes (Berges 1998). Admittedly, the results that are forthcoming from these studies are by no means conclusive, perhaps because the editors had a variety of purposes, but the probing that has begun suggests new ways of approaching Isaianic studies. In this approach, we may be concerned to ask questions about what the editors of the canonical book of Isaiah intended to convey with the final composition - as we have it in front of us. It is important to note that the net result of this recent interest in the canonical book of Isaiah is to place it into the same arena in which most biblical books, for decades, have found themselves: one where they are treated as unified compositions and are mined for the treasures to be found in their whole message, as well as in their component parts.

A second area in which there has been far-reaching changes in the past few decades is the study of Hebrew poetry. These studies naturally range beyond the book of Isaiah, although Isaiah 1-12 is mostly in the form of Hebrew poetry. Poetic analysis has recourse to different approaches which are all - taken in sensu lato - within the domain of literary theory: poetology, structural analysis of different provenance, metaphor research, aesthetic theory of style and rhetoric, reader-response-criticism etc (Spieckermann 1998:144). These different analyses are combined with the so-called "final-text exegesis", which attempts to take the end form of the text seriously as opposed to the historical-critical exegesis which (sometimes) 
attaches more importance to the first or more original form of the text $\mathrm{t}^{24}$.

In order to interpret for example the Isaianic text, it is necessary to relate its text to intertexts of various sorts: social, cultural, political, religious, methodological, epistemological, cosmological, etcetera. To write a commentary is to re-inscribe the Biblical text, that is to say, to prepare a palimpsest, or more correctly, to re-inscribe an existing palimpsest (cf Polak 1988). Intertextuality relies heavily on structural analysis in seeing all signs, including those in a literary text, as meaningful insofar as they stand in relation and opposition to other signs (Sommer 1998:7). As a result, any utterance is only significant within the context of other utterances, or as part of a sign system, such as a language. To understand any utterance is to put it into relationship with other utterances, and thus, any reader of a literary text necessarily connects it with other utterances. These utterances include other literary texts as well as expressions and underlying ideologies. This approach thus regards texts as part of a larger set of signifying systems, and only in such systems can they come into being or can they be understood.

Intertextuality therefore encompasses manifold connections between a text being studied and other texts, or between a text being studied and commonplace phrases or figures from the linguistic or cultural systems in which the text exists. It is important to note that these connections do not arise exclusively from an intentional and signalled use of an earlier text, such as a citation. The connections may result from the way in which expressions in a given text reflect linguistic, aesthetic, cultural, or ideological contexts of the text at hand. Other texts may share those contexts, and hence links among many texts may be noticed, whether the authors of the texts were familiar with each other or not.

The fact must thus be recognised that Old Testament scholarship, at the beginning of the $21^{\text {st }}$ century, is faced

24 See Zenger (1994:43). Compare in this regard also WS Prinsloo (1985:2): "Historical criticism must face the charge that, on the strength of its romantic supposition that the earliest source is the most authentic or the best, it has often failed to take proper account of the final text. In its attempt at reconstructing the so-called 'original' text it makes so much of the origin and growth of the final version that the latter is largely neglected." 
methodologically with a fundamental challenge, namely to combine synchronic and diachronic textual reading. It is thus no longer a question of either synchronic or diachronic reading of a specific text. Synchronic reading can no longer regard historical refinement as a redundant endeavour - the same can be postulated for the opposite $^{25}$.

In this regard Berges (2000:170) infers as follows: "Die Herausforderung an die aktuelle alttestamentliche Exegese liegt nicht in einem methodologischen aut-aut von Diachronie oder Synchronie, sondern in einem spannungsvollen et-et. Einer so geforderten 'diachron reflektierten Synchronie' methodisch und inhaltlich den Weg zu bahnen, scheint die Aufgabe der Zukunft zu sein" 26 . We are thus in need of a marriage of structural and historical awareness within the perceiving mind of the exegete. An exegete has to be trained to be constantly on the lookout for all sorts of structural and historical indicators in the text and to integrate them into the process of understanding. From this integrated process of perceiving he/she has to create his/her story (or narrative) of what the text means (Deist 1983:86-87) ${ }^{27}$.

This new theoretical understanding therefore necessitates $a$ diachronically reflected synchronic reading of the text. The diachronic consideration explains the synchronic fact and the synchronic interpretation still demands the incalculation of the time factor; that is to say they are inextricably intertwined and linked to one another. Therefore, it can be deduced that synchronic analysis

25 In this regard Beuken (2003:11) concludes as follows: "Der zeitgenössische Ausleger hat die Aufgabe, den Abstand zwischen der Leserschaft von damals und heute zu überbrücken. Diesen Abstand in einer Art "radikaler Synchronie« nicht zu berücksichtigen, hieße, die geschichtliche Dimension des Jesajatextes $\mathrm{zu}$ missachten, und würde $\mathrm{zu}$ gravierenden Fehlinterpretationen führen".

26 Cf furthermore Berges (2008:3): "Die zum Teil heftig geführte Diskussion zwischen diachronen und synchronen Auslegungsweisen, also solchen, die zum einen die Entstehung, zum anderen die Geltung des vorliegenden Endtextes zu eruieren suchen, hat unzweifelhaft mit dazu geführt, die biblischen Bücher und Buchsammlungen als literarische Kompositionen zu begreifen, die über Jahrhunderte gewachsen sind."

27 See also Barton (1994:15); Beuken (1994:26-27); Deist (1995:44-47); Dohmen (2003:167-169); Human (1999:357-360); Joyce (1995:127); Rendtorff (1993:52); Ryou (1995:4-7); Talstra (1993:264-265); Talstra (1995:207-208). 
without diachronic input seems to touch only the textual surface (Barr 1995:7; Deist 1995:46) ${ }^{28}$.

\section{CONCLUSION}

In this article I have outlined my stance with regard to the request I received to contribute two volumes on Isaiah in the HCOT commentary series. In this article I briefly discussed recent developments in the study of the book of Isaiah, as well as my own objectives and hypothesis with regard to this project. A short overview of Isaiah 1-12 on a synchronic level was given, as well as my research methodology (a "diachronically reflected synchronic") was discussed.

The textual analysis in this study will indicate that the text of Isaiah 1-12 is the product of a multi-stage redactional-compositional process. A thorough text-immanent (literary) analysis, combined with an inter-textual and extra-textual (historical) analysis, will indicate a developmental history of the text of Isaiah 1-12 in different layers. These chapters were written over the course of many centuries. The book of Isaiah is simultaneously a "literary piece of art" (synchrony), a time-historical witness and the end-product of nearly five hundred years' history of growth of the book (diachrony).

In order to conclude this article I will make some final remarks. The basic tenet of this project can be summarised as follows: I adhere to the viewpoint that the Hebrew Bible was and is a vehicle of knowledge of God. This knowledge was originally imparted at specific times and places within the bounds of human history. In order for us to recognise and accept the validity of that knowledge, we must realise that the Hebrew Bible originated in a human society which, with respect to the basic realities of the human condition, was not so very different from our own (Beuken 2000:x). It was in the context of a fundamentally similar society, in the concreteness of ordinary human history, culture and language, that the revelation of Yahweh - the God of Israel - was received through the centuries. It is only by concentrating on the specificity of that thoroughly historical revelation, which is often brought into focus by

28 In this regard Spieckermann (1998:145) postulates as follows: "Synchrone Textbeschreibung bleibt ohne diachrone Analyse oberflächlich. Diachrone analyse bleibt ohne Ausrichtung auf die Synthese und das dort gegebene synchrone Miteinander der Textelemente museal." 
comparing the traditions of Israel with those of its neighbours, that we can hope to grasp the uniqueness of ancient Israel's faith.

\section{Consulted literature}

Ackroyd, P R 1978. Isaiah I-XII, in Emerton, J A (ed), Congress Volume Göttingen 1977, Leiden: Brill (VT.S 29), 16-48.

Baker, D W 1999. Israelite prophets and prophecy in Baker, D W \& Arnold, B $\mathrm{T}$ (eds), The face of Old Testament studies. A survey of contemporary approaches. Grand Rapids, MI: Baker Books, 266-294.

Barr, J 1995. The synchronic, the diachronic and the historical: a triangular relationship? in De Moor, J C (ed), Synchronic or diachronic? A debate on method in Old Testament exegesis. Leiden: Brill (OTS 34), 1-14.

Barthel, J 2003. Das Problem des historischen Jesaja, in Fischer, I et al (Hrsg), Prophetie in Israel. Beiträge des Symposiums "Das Alte Testament und die Kultur der Moderne« anlässlich des 100. Geburtstags Gerhard von Rads (1901-1971) Heidelberg, 18.-21. Oktober 2001, Münster: LitVerlag (ATM 11), 125-135.

Barton, J 1994. Historical criticism and literary interpretation: is there any common ground? in Porter, S E, Joyce, P M \& Orton, D E (eds), Crossing the boundaries: essays in biblical interpretation in honour of Michael D Goulder, Leiden: Brill (Bibl.-Interpr.S 8), 3-15.

Becker, J 1968. Isaias - der Prophet und sein Buch. Stuttgart: Katholisches Bibelwerk (SBS 30).

Becker, U 1999. Jesajaforschung (Jes 1-39) in ThR 64, 1-37; 117-152.

-, 2003. Das Problem des historischen Jesaja, in Fischer, I et al (Hrsg), Prophetie in Israel. Beiträge des Symposiums »Das Alte Testament und die Kultur der Moderne" anlässlich des 100. Geburtstags Gerhard von Rads (1901-1971) Heidelberg, 18.-21. Oktober 2001, Münster: LitVerlag (ATM 11), 117-124.

-, 2004. Die Wiederentdeckung des Prophetenbuches. Tendenzen und Aufgaben der gegenwärtigen Prophetenforschung in BThZ 21/1, 30-60.

Berges, U 1998. Das Buch Jesaja. Komposition und Endgestalt. Freiburg: Herder (HBS 16).

-, 1999. Sion als thema in het boek Jesaja. Nieuwe exegetische benadering en theologische gevolgen in $T v T 39,118-138$.

-, 2000. Die Zionstheologie des Buches Jesaja in EstB 58, 167-198.

-, 2006. Das Jesajabuch als literarische Kathedrale in BiKi 4, 190-197.

-, 2008. Das Jesajabuch als Jesajas Buch. Zu neuesten Entwicklungen in der Prophetenforschung in ThRv 104, 4-14.

Beuken, W A M 1994. The present state of Old Testament studies in Europe and foreseeable directions for the future in OTE 7/4, 25-32.

-, 2000. Isaiah. Part 2. Volume II: Isaiah 28-39. Leuven: Peeters (HCOT). 
-, 2003. Jesaja 1-12. Freiburg: Herders (HThKAT).

Blenkinsopp, J 2000. Isaiah 1-39. New York: Doubleday (AncB 19).

Childs, B S 2001. Isaiah. London: John Knox Press (OTL).

Davies, W D 1986. Reflections on thirty years of Biblical study in SJTh 39, 4364.

Deist, F 1983. Again: method(s) of exegesis. Reflections on text and reality in OTE 1, 73-88.

-, 1994. Ervaring, rede en metode in skrifuitleg. 'n Wetenskapshistoriese ondersoek na skrifuitleg in die Ned Geref Kerk 1840-1990. Pretoria: RGN (RGN-Studies in Metodologie).

-, 1995. On "synchronic" and "diachronic": Wie es eigentlich gewesen ist in JNSL 21(1), 37-48.

-, 1997. Inside a commentary. Reflections on the writing of Bible commentaries in OTE 10(3), 369-386.

De Jong, M J 2007. Isaiah among the Ancient Near Eastern Prophets. A comparative study of the earliest stages of the Isaiah tradition and the Neo-Assyrian prophets. Leiden: Brill (VT.S 117).

Dohmen, Chr 2003. Das Zelt ausserhalb des Lagers. Exodus 33,7-11 zwischen Synchronie und Diachronie, in Kiesow, K \& Meurer, Th (Hrsg), Textarbeit. Studien zu Texten und ihrer Rezeption aus dem Alten Testament und der Umwelt Israels. FS Peter Weimar, Münster: UgaritVerlag. (AOAT 294), 157-169.

Duhm, B 1892. Das Buch Jesaia. Göttingen: Vandenhoeck \& Ruprecht.

Hardmeier, C 1986. Jesajaforschung im Umbruch in $V F$ 31, 3-31.

Höffken, P 2004. Jesaja. Der stand der theologischen Diskussion. Darmstadt: WBG.

Human, D J 1999. Die literêr-historiese lees van 'n teks in SK 20(2), 354-368.

Jeremias, J 1999. Prophetenwort und Prophetenbuch. Zur Rekonstruktion mündlicher Verkündigung der Propheten in JBTh 14, 19-35.

Joyce, P M 1995. Synchronic and diachronic perspectives on Ezekiel, in De Moor, JC (ed.), Synchronic or diachronic? A debate on method in Old Testament exegesis, Leiden: Brill (OTS 34), 115-128.

Kaiser, O ${ }^{5}$ 1981. Das Buch des Propheten Jesaja. Kapitel 1-12. Göttingen: Vandenhoeck \& Ruprecht (ATD 17).

-, ${ }^{3}$ 1983. Der Prophet Jesaja. Kapitel 13-39. Göttingen: Vandenhoeck \& Ruprecht (ATD 18).

Köckert, M 2003. Das Problem des historischen Jesaja, in Fischer, I et al (Hrsg), Prophetie in Israel. Beiträge des Symposiums »Das Alte Testament und die Kultur der Moderne» anlässlich des 100. Geburtstags Gerhard von Rads (1901-1971) Heidelberg, 18.-21. Oktober 2001, Münster: Lit-Verlag (ATM 11), 105-116. 
Koole, J L 1997. Isaiah. Part 3. Volume I: Isaiah 40-48. Kampen: Kok (HCOT).

Körtner, U H J 2006. Einführung in die theologische Hermeneutik. Darmstadt: WBG.

Le Roux, J H 1993. A story of two ways. Thirty years of Old Testament scholarship in South Africa. Pretoria: Verba Vitae (OTE.S 2).

Oeming, M 1998. Biblische Hermeneutik. Eine Einführung. Darmstadt: WBG.

Oswalt, J N 1986. The book of Isaiah. Chapters 1-39. Grand Rapids, MI: Eerdmans.

PBC (Pontifical Biblical Commission) 1993. The interpretation of the Bible in the Church. Boston, MA: St. Paul Books.

Polak, F H 1988. Biblical narratives as a palimpsest: On the role of diachrony in structural analysis in $A C E B T$ 9, 22-34.

Prinsloo, W S 1985. The theology of the book of Joel. Berlin: Walter de Gruyter (BZAW 163).

Rendtorff, R 1984. Zur Komposition des Buches Jesaja in VT 34, 295-320.

-, 1993. The paradigm is changing: hopes - and fears in Bibl.Interpr 1(1), 3453.

Ryou, D H 1995. Zephaniah's oracles against the nations. A synchronic and diachronic study of Zephaniah 2:1-3:8. Leiden: Brill (Bibl.Interpr.S 13).

Schmid, K 2007. Hintere Propheten (Nebiim), in Gertz, J C (Hrsg), Grundinformation Altes Testament, Göttingen: Vandenhoeck \& Ruprecht (UTB 2745), 303-401.

Seebaß, H 1995. Art. "Jesaja (Buch)" in NBL 2, 315-318.

Sommer, B D 1998. A prophet reads scripture. Allusion in Isaiah 40-66. Stanford, California: Stanford University Press (Contraversions).

Spieckermann, H 1998. Psalmen und Psalter. Suchbewegungen des Forschens und Betens, in Martínez, FG \& Noort, E (eds), Perspectives in the study of the Old Testament and early Judaism: FS. A.S. van der Woude, Leiden: Brill (VT.S 73), 137-153.

Spronk, K 1997. Nahum. Kampen: Kok (HCOT).

Steck, O H 1995. Old Testament exegesis. A guide to the methodology. [Translated by J D Nogalski from the original German "Exegese des Alten Testaments" $\left(1993^{13)}\right.$ ]. Atlanta, Georgia: Scholars Press (SBL RBS $33)$.

-, 1996. Die Prophetenbücher und ihr theologisches Zeugnis. Wege der Nachfrage und Fährten zur Antwort. Tübingen: Mohr (Siebeck).

Sweeney, M A 1988. Isaiah 1-4 and the post-exilic understanding of the Isaianic tradition. Berlin: Walter de Gruyter (BZAW 171).

-, 1993. The book of Isaiah in recent research in CR:BS 1, 141-162. 
-, 1996. Isaiah 1-39, with an introduction to prophetic literature. Grand Rapids, MI: Eerdmans (FOTL 16).

-, 2005. Form and intertextuality in prophetic and apocalyptic literature. Tübingen: Mohr Siebeck (FAT 45).

Talstra, E 1993. Solomon's prayer. Synchrony and diachrony in the composition of I Kings 8, 14-61. Kampen: Kok Pharos (CBET 3).

-, 1995. Deuteronomy 9 and 10: synchronic and diachronic observations, in De Moor, J C (ed), Synchronic or diachronic? A debate on method in Old Testament exegesis, Leiden: Brill (OTS 34), 187-210.

Tate, M E 1996. The book of Isaiah in recent study, in Watts, JW \& House, PR (eds), Forming prophetic literature. Essays on Isaiah and the Twelve in honor of John D.W. Watts, Sheffield: Sheffield Academic Press (JSOT.S 235), 22-56.

Von Rad, G 1968. Theologie des Alten Testaments. Band II. Die Theologie der prophetischen Überlieferungen Israels. München: Chr. Kaiser Verlag.

Wildberger, H 1965-82. Jesaja 1-39, 3 vols. Neukirchen-Vluyn: Neukirchener Verlag (BKAT X).

Zenger, E 1994. New approaches to the study of the Psalms in PIBA 17, 37-54. 